\title{
KONDISI SISTEM KARDIOVASKULAR DAN KEJADIAN NYERI TUNGKAI BAWAH SESUDAH LARI SPRINT 400 METER PADA SISWA SEKOLAH OLAHRAGA
}

\author{
Mujahidin \\ Dosen Program Studi Ilmu Keperawatan STIK Bina Husada Palembang \\ Jl. Syech Abdul Somad No. 28 Kel. 22 Ilir Palembang \\ Email : mujahidinners@yahoo.com
}

\begin{abstract}
Abstrak
Beberapa penelitian tentang lari ataupun kondisi nyeri yang terjadi akibat dari melakukan aktivitas tersebut sudah pernah dilakukan, namun dalam kesempatan ini peneliti ingin mengungkapkan beberapa hal tentang kondisi kardiovaskular yang meliputi frekuensi nadi, tekanan darah dan kejadian nyeri tungkai bawah setelah melakukan lari sprint 400 meter. Penelitian ini merupakan penelitian kuantitatif deskriptif dengan pendekatan cross sectional. Sampel dalam penelitian ini adalah siswa SMA jurusan olahraga kelas X berjumlah 30 orang yang dipilih dengan menggunakan tehnik purposive sampling serta memenuhi kriteria yang telah ditentukan. Penelitain ini dilaksanakan pada bulan Juni 2019. Dalam penelitian ini dilakukan pengukuran terhadap tinggi badan, berat badan, frekuensi nadi, tekanan darah dan kondisi nyeri tungkai bawah setelah melakukan lari sprint 400 meter. Selanjutnya data diolah dan disajikan dalam bentuk tabel distribusi frekuensi. Berdasarkan hasil penelitian diketahui jika rata-rata denyut nadi $69,87 \mathrm{x} /$ menit dengan denyut nadi terendah frekuensi $63 \mathrm{x} / \mathrm{menit}$ dan frekuensi nadi tertinggi $80 \mathrm{x} / \mathrm{menit}$. Diketahui jika rata-rata tekanan darah sistolik $111,0 \mathrm{mmHg}$ dengan tekanan sistolik terendah $100 \mathrm{mmHg}$ dan tertinggi $120 \mathrm{mmHg}$. Diketahui jika rata-rata tekanan darah diastolik $66,17 \mathrm{mmHg}$ dengan tekanan darah diastolik terendah $60 \mathrm{mmHg}$ dan tertinggi 80 $\mathrm{mmHg}$. Diketahui jika rata-rata intensitas nyeri tungkai bawah setelah lari sprint 400 meter adalah 5,03 dengan intensitas nyeri tertinggi 7 dan terendah 2. Dari data diatas dapat disimpuklkan bahwa frekuensi nadi dan tekanan darah sistolik dan diastolik setelah siswa melakukan lari sprint 400 meter dalam kategori normal. Olahraga lari dapat memberikan manfaat kesehatan bagi tubuh apabila dilakukan dengan tehnik yang benar, waktu yang tepat dan teratur.
\end{abstract}

Kata Kunci : Sistem Kardiovaskular, Nyeri Tungkai Bawah, Lari Sprint 400 Meter

\section{Abstract}

Several studies on running or pain conditions that occured as a result of carrying out these activities had been carried out, but on this occasion the researchers wanted to reveal several things about cardiovascular conditions including pulse frequency, blood pressure and the incidence of lower limb pain after sprinting for 400 meters. This research is a descriptive quantitative research with cross sectional approach. The sample in this study were 30 students of $10^{\text {th }}$ grade of high school in sport major that selected using purposive sampling techniques and meeting predetermined criteria. This research was carried out in June 2019. In this study measurements were taken of height, weight, pulse frequency, blood pressure and lower limb pain conditions after a 400 meter sprint running. Then the data was processed and presented in the form of a frequency distribution table. Based on the results of the study, it is known that the average pulse rate is $69.87 \mathrm{x} /$ minute with the lowest pulse frequency of $63 \mathrm{x} /$ minute and the highest pulse frequency of $80 \mathrm{x} /$ minute. It is known that the average of systolic blood pressure is $111.0 \mathrm{mmHg}$ with the lowest systolic pressure of $100 \mathrm{mmHg}$ and the highest is $120 \mathrm{mmHg}$. It is known that the average of diastolic blood pressure is $66.17 \mathrm{mmHg}$ with the lowest diastolic blood pressure of 60 $\mathrm{mmHg}$ and the highest $80 \mathrm{mmHg}$. It is known that the average of intensity of lower limb pain after a 400 meter sprint running is 5.03 with the highest pain intensity of 7 and the lowest 2 . From the data above it can be concluded that the pulse frequency and systolic and diastolic blood pressure after students perform 400 meter sprints in the normal category. Running can provide health benefits for the body if it is done with the right technique, the right time and regularly.

Keywords : Cardiovascular System, Lower Limb Pain, Sprint Run 400 Meters 


\section{PENDAHULUAN}

Olahraga merupakan aktifitas fisik yang mempunyai banyak manfaat terhadap kehidupan manusia, diantaranya untuk kesehatan, pendidikan, rekreasi dan prestasi.

Salah satu dari cabang olahraga adalah olahraga lari, dimana lari memiliki banyaka manfaat untuk kesehatan tubuh manusia. macam-macam lari di tentukan oleh Nomor lari berdasarkan jarak yang ditempuh dibedakan menjadi: lari jarak pendek sprint mulai dari 60 sampai 400 meter, lari jarak menengah (middle distance) mulai dari jarak 800 meter sampai 1500 meter, danlari jarak jauh (long distance) mulai dari jarak 3000 meter sampai dengan 42,195 km (marathon) (Wiarto,2013). Nyeri seringkali dijelaskan dalam istilah proses distruktif jaringan seperti ditusuk-tusuk, panas terbakar, melilit, seperti emosi, pada perasaan takut, mual dan mabuk. Terlebih lagi, setiap perasaan nyeri dan intensitas sedang sampai kuat disertai oleh rasa cemas dan keinginan kuat untuk melepaskan diri dari perasaan itu (Judha, 2012)

Nyeri merupakan perasaan tidak nyaman, baik ringan maupun berat yang hanya dapat dirasakan oleh individu tersebut tanpa dapat dirasakan oleh orang lain, mencakup pola pikir, aktifitas senda dan gejala seseorang secara langsung dan perubahan hidup seseorang. Nyeri merupakan tanda dan gejala penting yang dapat menunjukkan telah terjadinya gangguan fisiologis (priyoto, 2015)

Nyeri di uraikan sebagai sensasi tidak menyenangkan yang terasa jika ujung syaraf tertentu (nosiseptor) terstimulasi. Nyeri bersifat unik dan subjektif, terdiri dari sensasi fisiologis dan respon emosi. Intensitas nyeri bervariasi mulai dari berat sampai ke ringan, tetapi respon individu di pengaruhi oleh factor-faktor seperti pengetahuan tentang penyebab, lokasi, usia, penyakit terkait, baik akut maupun kronik, dan toleransi nyeri, (Brooker, 2013)

Tindakan nonfarmakologis atau mandiri perawat itu ada beberapa cara diantaranya adalah distraksi dan relaksasi, tehnik distraksi yaitu untuk nyeri yang dirasakan sesaat seperti injeksi dan pengambilan darah. Sedangkan tehnik relaksasi yaitu meditasi, yoga, musik dan ritual keagamaan. Penggunaan tehnik relaksasi tidak menyiratkan bahwa nyeri itu tidak ada tetapi untuk menurunkan dan mengurangi ketakutan atau kecemasan yang berhubungan dengan nyeri, (Charles,2010).

Pada kondisi berolahraga, tubuh akan mengalami berbagai macam perubahan perubahan fisiologis yang itu terjadi sebagai upaya kompensasi terhadap kondisi pada tubuh yang terjadi ketika melakukan olahraga. Seperti pada olahraga lari misalnya, denyut jantung akan lebih cepat dari biasanya dikarenakan jantung harus mencukupi kebutuhan oksigen dalam jumlah besar ke jaringan otot.

\section{Tujuan Penelitian}

Tujuan Umum

Untuk mengetahui gambaran kondisi kardiovaskular dan kejadian nyeri tungkai bawah setelah lari sprint 400 meter

\section{Tujuan Khusus}

Penelitian ini bertujuan untuk mengetahui distribusi frekuensi dan ratarata denyut nadi siswa setelah melakukan lari sprint 400 meter

Penelitian ini bertujuan untuk mengetahui distribusi frekuensi dan ratarata tekanan darah sistolik dan diastolik siswa setelah melakukan lari sprint 400 meter.

Penelitian ini bertujuan untuk mengetahui distribusi frekuensi dan ratarata kejadian nyeri tungkai bawah siswa setelah melakukan lari sprint 400 meter

\section{Manfaat Penelitian}

Bagi Institusi Pendidikan diharapkan dapat menambah informasi baru guna menciptakan lulusan yang berkualitas.

Bagi peneliti/Dosen diharapkan dapat menambah wawasan dan ilmu serta dapat meningkatkan profesionalitas sehingga 
dapat menyalurkan ilmu kepada mahasiswa sehingga pada akhirnya dapat menciptakan lulusan yang berkompetensi.

Bagi Mahasiswa dan Siswa diharapkan dapat menambah wawasan informasi khususnya terkait olahraga dan nyeri

Bagi peneliti selanjutnya diharapkan dapat menjadi bahan rujukan untuk proses penelitian lebih lanjut.

\section{METODE PENELITIAN}

Penelitian ini merupakan penelitian kuantitatif deskriptif dengan pendekatan cross sectional. Sampel dalam penelitian ini adalah siswa jurusan olahraga kelas $\mathrm{X}$ berjumlah 30 orang yang dipilih dengan menggunakan tehnik purposive sampling serta memenuhi kriteria yang telah ditentukan.

Kriteria Inklusi

1) Siswa jurusan olahraga

2) Kelas $X$

3) Laki-Laki

4) Bersedia/Diizinkan Orang Tua/Wali Berpartisipasi dalam kegiatan penelitian

Kriteria Ekslusi

a) Siswa yang tidak dalam kondisi sehat ketika pelaksanaan kegiatan penelitian.

Penelitain ini dilaksanakan pada bulan Juni 2019.

Alat dan bahan yang digunakan

a. Stopwatch

b. Formulir Penilaian

\section{Alur Penelitian}

a. Menjelaskan kepada siswa tentang rencana penelitian yang akan dilakukan.

b. Memilih siswa yang berpartisipasi dalam proses penelitian.

c. Pelaksanaan Penelitian

d. Pengolahan data hasil penelitian

e. Penyusunan laporan hasil penelitian
Setelah semua data terkumpul, tahapan selanjutnya adalah melakukan entry data ke dalam komputer. Analisis univariat dilakukan untuk melihat distribusi frekuensi dan rata rata denyut nadi, tekanan darah sistolik dan diastolic serta kejadian nyeri tungkai bawah. Semua prosedur pengolahan dan analisis data dilakukan dengan menggunakan program SPSS Versi 19.

\section{HASIL PENELITIAN Frekuensi Nadi}

Hasil penelitian terhadap 30 orang siswa di sekolah olahraga sriwijaya Palembang, dimana terdapat variabel nadi . adaapun distribusi frekuensi nya sebagai berikut ;

Tabel 1.

Frekuensi Nadi

\begin{tabular}{ccc}
\hline Frekuensi Nadi & Frekuensi & $(\%)$ \\
\hline 63 & 1 & 3,3 \\
64 & 2 & 6,7 \\
65 & 3 & 10,0 \\
67 & 1 & 3,3 \\
68 & 3 & 10,0 \\
69 & 1 & 3,3 \\
70 & 4 & 13,3 \\
72 & 3 & 10,0 \\
73 & 1 & 3,3 \\
72 & 3 & 10,0 \\
73 & 1 & 3,3 \\
74 & 1 & 3,3 \\
75 & 4 & 13,3 \\
76 & 1 & 3,3 \\
78 & 2 & 6,7 \\
80 & 2 & 6,7 \\
\hline
\end{tabular}

Hasil dapatkan nilai rata-rata dari variabel nadi pada siswa olahraga sriwijaya Palembang 69,87 x / menit. Dengan frekuensi $60 \mathrm{x} /$ menit 1 orang $3,3 \%, 63 \times$ /menit 1 orang atau 3;3\% $64 \mathrm{x}$ / menit 2 orang atau $6,7 \%, 65 \mathrm{x} /$ menit 3 orang atau $10,0 \%, 67 \mathrm{x} /$ menit 1 orang $3,3 \%, 68 \times /$ menit 3 orang atau $10,0 \%$, $69 \mathrm{x} /$ menit1 orang 3,3\%, $70 \mathrm{x} /$ menit 4 orang atau $13,3 \%, 72 \times /$ menit ada 3 orang atau $10,0 \%, 73 \times /$ menit 1 orang atau $3,3 \%, 74 \mathrm{x} /$ menit 1 orang atau $3,3 \%, 75 \times /$ menit 3 orang atau $10,0 \%$, 
$76 \mathrm{x} /$ menit 1 orang atau $3,3 \%, 78 \mathrm{x} /$ menit 2 orang atau $6,7 \%, 80 \mathrm{x} /$ menit 2 orang atau $6,7 \%$, total $100 \%$ atau 30 responden.

\section{Tekanan darah sistol.}

Hasil penelitian terhadap 30 orang siswa di sekolah olahraga sriwijaya Palembang, dimana terdapat variable tekanan darah sistol. adaapun distribusi frekuensi nya sebagai berikut ;

Tabel 2.

Tekanan Darah Sistol

\begin{tabular}{ccc}
\hline $\begin{array}{c}\text { Tekanan } \\
\text { Darah Sistol }\end{array}$ & Frekuensi & $\%$ \\
\hline 100 & 7 & 23,3 \\
110 & 13 & 43,3 \\
120 & 10 & 33,3 \\
\hline
\end{tabular}

Hasil didapatkan rata-rata tekanan darah sistol 111.00 mmhg .dengan tekanan darah sistol paling rendah 100 dan yang palng tinggi 120. Dengan frekuensi sebagai berikut : Tekanana darah 100 berjumlah 7 responden atau $23,3 \%$, tekanan darah sistol 110 berjumlah 13 responden atau 43,3\%, , 120 mmhg berjumlah 10 responden atau $33,3 \%$. Dengan total responden $30100 \%$.

\section{Tekanan darah diastole}

Hasil penelitian terhadap 30 orang siswa di sekolah olahraga sriwijaya Palembang , dimana terdapat variable tekanan darah diastol. adaapun distribusi frekuensi nya sebagai berikut:

Tabel 3.

Tekanan Darah Sistol

\begin{tabular}{|c|c|c|}
\hline $\begin{array}{c}\text { Tekanan } \\
\text { Darah Sistol }\end{array}$ & Frekuensi & $\%$ \\
\hline 100 & 7 & 23,3 \\
\hline 110 & 13 & 43,3 \\
\hline 120 & 10 & 33,3 \\
\hline
\end{tabular}

Hasil didapatkan rata-rata tekanan darah diastole 66,175.Dengan nilai minimum 60 dan maximum 80. Dengan frekuensi 60 mmhg 15 orang atau 50,0\%, $70 \mathrm{mmhg}$ 11 orang atau $36,7 \%, 75$ mmhg 1 responden $3,3 \%$ dan 80 mmhg 3 orang
10.0\%. total responden $30 / 100 \%$.

Hasil penelitian kejadian nyeri tungkai bawah setelah lari sprint 400 meter terhadap 30 orang siswa sekolah olahraga sriwijaya Palembang tahun 2019.

Tabel 4.

Kejadian Nyeri Tungkai Bawah Setelah Lari Sprint 400 Meter

\begin{tabular}{ccc}
\hline $\begin{array}{c}\text { Intensitas Nyeri } \\
\text { Tungkai Bawah }\end{array}$ & Frekuensi & $\%$ \\
\hline 2 & 1 & 3.3 \\
3 & 3 & 10.0 \\
4 & 4 & 13.3 \\
5 & 9 & 30.0 \\
6 & 12 & 40.0 \\
7 & 1 & 3.3 \\
\hline Total & $\mathbf{3 0}$ & $\mathbf{1 0 0 . 0}$ \\
\hline
\end{tabular}

Hasil didapatkan terbanyak intensitas nyeri 6 atau kategori sedang sebanyak 12 (40\%) dan intensitas nyeri 2 atau kategori ringan sebanyak $1(3.3 \%)$.

Tabel 5.

Rata-Rta Kejadian Nyeri Tungkai Bawah Setelah Lari Sprint 400 Meter

\begin{tabular}{lllll}
\hline Variabel & Mean & SD & $\begin{array}{l}\text { Min- } \\
\text { Max }\end{array}$ & $\begin{array}{l}95 \% \\
\text { CI }\end{array}$ \\
\hline Kejadian & 5,03 & 1,1 & $2-7$ & $4,59-$ \\
Nyeri & & 89 & & 5,48 \\
Tungkai & & & & \\
Bawah & & & & \\
$\quad$ Setelah & & & & \\
\hline Lari Sprint & & & & \\
400 Meter & & & & \\
\hline
\end{tabular}

Hasil analisis di dapatkan nilai ratarata

5.03 (95\% CI : 4,59-5,48) . dengan standar deviasi 1.189. skala nyeri terendah 2 dan yang tertinggi 7 . dari hasil estimasi interval di dapatkan kesimpulan bahwa 95\% diyakini bahwa nyeri sebelum dilakukan terapi music adalah diantara 4,59 sampai dengan 5,48.

\section{Pembahasan}

Hasil penelitian yang telah dilakukan kepada 30 orang siswa Sekolah Olahraga 
Sriwijaya didapatkan beberapa informasi terkait frekuensi denyut nadi setelah melakukan lari sprint 400 meter. Rata-rata denyut nadi $69,87 \mathrm{x} /$ menit dengan frekuensi nadi tertinggi yaitu $80 \mathrm{x} /$ menit sebanyak 2 orang siswa $(6,7 \%)$ dan frekuensi nadi terendah yaitu $63 \mathrm{x} /$ menit sebanyak 1 orang siswa $(3,3 \%)$.

Sementara untuk kondisi tekanan darah didapatkan informasi jika rata rata tekanan darah sistolik setelah melakukan lari sprint 400 meter yaitu $111.00 \mathrm{mmHg}$ dengan tekanan darah sistolik paling tinggi yaitu $120 \mathrm{mmHg}$ dan tekanan darah terendah yaitu $100 \mathrm{mmHg}$. Rata- rata tekanan darah diastolic yaitu $66,175 \mathrm{mmHg}$ dengan tekanan darah diastolic tertinggi yaitu $80 \mathrm{mmHg}$ dan terendah yaitu 60 $\mathrm{mmHg}$.

Pada kejadian nyeri didapatkan informasi jika rata rata intensitas nyeri tungkai bawah yang terjadi setelah melakukan lari sprint 400 meter yaitu intensitas 5,03 (Nyeri sedang) dengan intensitas nyeri tertinggi yaitu 7 dan intensitas nyeri ringan yaitu 2 .

Kondisi nyeri pada area tungkai bawah yang terjadi setelah melakukan olahraga lari sprint sangat memungkinkan untuk terjadi, hal ini dikarenakan pada olahraga lari seseorang akan melakukan gerakan yang sama, berulang dan dalam intensitas yang tinggi terutama pada otot otot ekstremitas bagian bawah, hal ini memungkinkan untuk terjadinya kontraksi. Proses glikolisis atau proses dimana glikogen yang disimpan di dalam otot dipecah menjadi glukosa untuk digunakan sebagai sumber energi yang terjadi tanpa menggunakan oksigen atau yang disebut dengan metabolisme anaerobic, pada tahap ini melokul glukosa dipecah menjadi dua molekul asam piruvat dan energi dilepaskan untuk membentuk empat molekul ATP. Biasanya asam piruvat akan masuk ke dalam mitokondria sel otot dan bereaksi dengan oksigen untuk membentuk lebih banyak molekul ATP. Akan tetapi jika tidak terdapat oksigen yang cukup untuk melangsungkan metabolisme glukosa tahap ini, asam piruvat akan dirubah menjadi asam laktat yang berdifusi keluar dari sel otot masuk ke dalam cairan interstitial dan rah, oleh karena itu banyak glikogen otot berubah menjadi asam laktat.

Mekanisme terjadinya nyeri pada kondisi setelah melakukan olahraga lari dapat terkait dengan adanya stimulus nyeri yang hal ini dapat terjadi karma pembentukan asam laktat, otot yang kaku, kerusakan jaringan dan proses inflamasi, (Torres, 2007).

Nyeri sebenarnya adalah suatu mekanisme protektif dari tubuh yang pada akhirnya menimbulkan kesadaran bahwa pada tubuh sedang atau akan mengalami terjadinya proses kerusakan jaringan. Sensari nyeri yang terjadi biasanya disertai dengan respon indivividu yang mengalami nyeri tersebut dengan menarik atau bertahan terhadap nyeri yang dirasakan. Untuk respon menarik, sebagai contoh ketika kita terkena percikan minyak panas, maka seketika tubuh merespon dengan menarik bagian tubuh yang terkena percikan minyak tersebut kemudian menghindar. Sedangkan untuk respon yang bertahan, biasanya jenis nyeri ini adalah nyeri yang bersifat sudah menetap dan tidak bisa lagi dihindari sehingga tidak ada pilihan bagi individu kecuali bertahan, misalnya nyeri pada kondisi patah tulang ataupun nyeri yang terjadi pasca berolahraga. Nyeri juga dipengaruhi pengalaman masa lalu yang hal ini memungkinkan seseorang yang telah beberapa kali mengalami nyeri yang disebabkan oleh suatu sebab yang sama akan cenderung lebih tahan terhadap nyeri yang dialaminya.

Reseptor mekanis, reseptor suhu dan reseptor polimodal adalah tiga reseptor nyeri atau yang sering juga disebut dengan nosireseptor. Reseptor ini mempunyai peranan yang berbeda dalam menangkap sensasi nyeri. Reseptor mekanis berespon 
terhadap kondisi yang berhubungan dengan terjadinya kerusakan mekanis seperti pada kondisi mengalami luka, patah tulang. Reseptor suhu berespon pada kondisi yang berkaitan dengan suhu seperti panas dan yang ketiga yaitu reseptor polimodal berespon terhadap kerusakan jaringan yang disebabkan karma bahan kimia.

Sinyal nyeri yang diterima oleh reseptor nyeri selanjutnya dikirim ke susunan saraf pusat melalui system saraf aferen. Untuk sinyal yang berasal dari reseptor mekanis dan reseptor suhu dikirimkan melalui serat A - Delta halus bermielin dengan kecepatan $30 \mathrm{~m} /$ detik. Sedangkan untuk sinyal dari reseptor polimodal dikirim oleh serat $\mathrm{C}$ halus tak bermielin dengan kecepatan yang jauh lebih lambat.

\section{KESIMPULAN}

Rata-rata frekuensi nadi 69,87 x / menit. Dengan frekuensi $60 \times$ / menit 1 orang $3,3 \%, 63 \times$ x /menit 1 orang atau $3 ; 3 \% 64 \times$ /menit 2 orang atau $6,7 \%, 65 \times$ / menit 3 orang atau 10,0\%, $67 \mathrm{x} /$ menit 1 orang 3,3\%, $68 \times$ /menit 3 orang atau 10,0\%, $69 \times$ / menit1 orang 3,3\%, 70 x / menit 4 orang atau $13,3 \%, 72 \times$ /menit ada 3 orang atau $10,0 \%, 73 \mathrm{x} /$ menit 1 orang atau 3,3\%, $74 \mathrm{x} /$ menit 1 orang atau 3,3\%, $75 \mathrm{x} /$ menit 3 orang atau $10,0 \%, 76 \mathrm{x} /$ menit 1 orang atau $3,3 \%, 78 \mathrm{x} /$ menit 2 orang atau 6,7\%,80x / menit 2 orang atau $6,7 \%$, total $100 \%$ atau 30 responden.

Rata-rata tekanan darah sistol 111.00 mmhg .dengan tekanan darah sistol paling rendah 100 dan yang paling tinggi 120 . Dengan frekuensi sebagai berikut : Tekanana darah 100 berjumlah 7 responden atau $23,3 \%$, tekanan darah sistol 110 berjumlah 13 responden atau 43,3\%, , 120 mmhg berjumlah 10 responden atau 33,3\%. Dengan total responden $30100 \%$. Rata-rata tekanan darah diastole 66,175. Dengan nilai minimum 60 dan maximum 80 . Dengan frekuensi $60 \mathrm{mmhg} 15$ orang atau $50,0 \%$, 70 mmhg 11 orang atau $36,7 \%$,
75 mmhg 1 responden $3,3 \%$ dan 80 mmhg 3 orang $10.0 \%$. total responden $30 / 100 \%$.

Rata-rata 5.03 (95\% CI : 4,59-5,48) dengan standar deviasi 1.189. skala nyeri terendah 2 dan yang tertinggi 7 . dari hasil estimasi interval di dapatkan kesimpulan bahwa $95 \%$ diyakini bahwa nyeri sebelum dilakukan terapi music adalah diantara 4,59 sampai dengan 5,48.

\section{SARAN}

\section{Bagi Mahasiswa dan Bagi Siswa}

Menambah wawasan dan keilmuan khususnya tentang olahraga lari dan nyeri.

\section{Bagi Institusi Pendidikan}

Sebagai literature untuk menambah wawasan dan pengetahuan dalam menganalisa masalah kesehatan khusunya di bidang nyeri.

\section{Bagi Peneliti Selanjutnya}

Sebagai data tambahan untuk penelitian lebih lanjut

\section{DAFTAR PUSTAKA}

Amalia Amirul.2017. Efektifitas Terapi Music Terhadap Nyeri Disminorea .Artikel. STIKESMuhammadiah Lamongan.

Astuti Ani \& Merdekawati Diah .2016. Pengaruh Terapi Music Klasik

Terhadap Penurunan Tingkat Skala Nyeri Pasien Post Operasi .Jurnal. Program Study Ilmu Keperawatan Stikes Harapan Ibu Jambi.

Cholifah, Noor, Setyowati, dan Sri Karyati. 2019.

Pengaruh Pemberian Terapi Musik Suara Alam Terhadap Penurunan Tekanan Darah Pada Penderita Hipertensi Di Desa Pelang Mayong Jepara Tahun 2016. Jurnal Ilmu Keperawatan dan Kebidanan Vol.10 No.1 (2019) 236-242

Judha ,Et All. 2012. Teori Pengukuran 
Nyeri \& Nyeri Bersalin. Yogyakarta.Nuha Medika.

Notoadmodjo Soekidjo. 2010. MetodelogiPenelitian Kesehatan. Jakarta. Aneka Cipta.

Nurdiansyah Tubagus Erwin. 2015. Pengaruh Terapi Music Klasik Terhadap Nyeri Pada Pasien Dengan Post Operasi Di RSUD.A.DADI Tjokrodipo Kota Bandar Lampung. Jurnal .Stikes Mitra Lampung.

Pearche Evelyn C.2011. Anatomi \& Fisiologi Untuk Para Medis. Jakarta. Gramedia Pustaka Utama.

Pearche Evelyn C.2013. Anatomi \& Fisiologi Untuk Para Medis .Jakarta. Gramedia Pustaka Utama.

Tarwoto ,Et All.2009. Anatomi Fisiologi Untuk Mahasiswa Keperawatan.Jakarta. Salemba Medika.

Trihandayani yani \& karnita ita .2011. Pengaruh terapi music terhadap penurunan intensitas nyeri akibat perawatan luka post operasi di ruang VII RSUD gunung djati Cirebon. jurnal. dosen akper muhammadiah Cirebon. 